\title{
Effects of Estrogen Treatment on Expression of Brain-Derived Neurotrophic Factor and cAMP Response Element-Binding Protein Expression and Phosphorylation in Rat Amygdaloid and Hippocampal Structures
}

\author{
Jin Zhou ${ }^{\mathrm{a}, \mathrm{c}}$ Huaibo Zhang ${ }^{\mathrm{b}, \mathrm{c}}$ Rochelle S. Cohen ${ }^{\mathrm{a}}$ Subhash C. Pandey ${ }^{\mathrm{a}-\mathrm{c}}$ \\ ${ }^{a}$ Department of Anatomy and Cell Biology and ${ }^{b}$ Department of Psychiatry, University of Illinois at Chicago, and \\ ' Jesse Brown Veterans Affairs Medical Center, Chicago, III., USA
}

\section{Key Words}

Gonadal steroids - Brain-derived neurotrophic factor - cAMP response element-binding protein . Immunocytochemistry · Amygdala $\cdot$ Hippocampus · Molecular neuroendocrinology $\cdot$ Calcium/calmodulin kinase

\begin{abstract}
Clinical studies indicate an effect of estrogen $\left(E_{2}\right)$ on affect and cognition, which may be mediated by the cAMP response element-binding protein (CREB) pathway and CREB-related gene target brain-derived neurotrophic factor (BDNF). We investigated the effect of $E_{2}$ on CREB expression and phosphorylation and BDNF expression in the amygdala and hippocampus, areas involved in emotional processing. Ovariectomized rats were given $10 \mu \mathrm{g} 17 \beta$-estradiol or vehicle for 14 days and expression of components of the CREB signaling pathway, i.e., CREB, phosphorylated CREB (pCREB), and BDNF in amygdala and hippocampus were investigated using immunogold labeling. Levels of BDNF mRNA were determined by in situ reverse-transcriptase polymerase chain
\end{abstract}

reaction. We also examined the effect of $E_{2}$ on calcium/ calmodulin kinase (CaMK IV) immunolabeling in the hippocampus. $E_{2}$ increased immunolabeling and mRNA levels of BDNF in the medial and basomedial amygdala and $\mathrm{CA} 1$ and $\mathrm{CA} 3$ regions of the hippocampus, but not in any other amygdaloid or hippocampal regions examined. $E_{2}$ increased immunolabeling of CREB and PCREB in the medial and basomedial, but not central or basolateral amygdala. $\mathrm{E}_{2}$ also increased CaMK IV and pCREB immunolabeling in the CA1 and CA3 regions, but not CA2 region or dentate gyrus, of the hippocampus. There was no change in immunolabeling of CREB in any hippocampal region. These data identify a signaling pathway through which $E_{2}$ increases BDNF expression that may underlie some actions of $E_{2}$ on affective behavior and indicate neuroanatomical heterogeneity in the $E_{2}$ effect within the amygdala and hippocampus.

Copyright (C) 2005 S. Karger AG, Basel

\section{KARGER}

(c) 2005 S. Karger AG, Basel

Fax +4161306 1234 E-Mail karger@karger.ch www.karger.com www.karger.com/nen
Rochelle S. Cohen

Department of Anatomy and Cell Biology

University of Illinois at Chicago, 808 S. Wood St. (M/C 512)

Chicago, IL 60612 (USA)

Tel. +1 312996 5166, Fax +1 312413 0354, E-Mail rscohen@uic.edu 


\section{Introduction}

Estrogen $\left(E_{2}\right)$ has been shown to have powerful growth effects in neurons [for reviews, see 1-3]. These include effects in areas relevant to reproduction, such as the ventromedial nucleus (VMN) of the hypothalamus, where various neuronal compartments exhibit ultrastructural signs of growth-like activity in response to $E_{2}$ treatment [4]. $E_{2}$ also exerts growth effects on synapses, such as those see in the midbrain central gray, where $\mathrm{E}_{2}$ treatment resulted in an increase in the number of synapses and length of postsynaptic densities [5]. In the VMN [6, 7], hippocampus [8], and amygdala [9], the appearance of dendritic spines is dependent upon variations in the estrous cycle or $E_{2}$ treatment itself. The actions of $E_{2}$ on synapses and dendritic spines may be indirect. Several studies implicate GABAergic neurons in the hippocampus as mediators of $E_{2}$ effects on hippocampal dendritic spines $[10,11]$. However, the precise mechanisms by which $E_{2}$ exerts its growth-like effects remains to be elucidated. The similarity between $\mathrm{E}_{2}$ actions and those of brain-derived neurotrophic factor (BDNF) [see reviews in 1,2$]$ suggest that this neurotrophic factor may be a likely candidate in mediating the effects of $E_{2}$ on some of the growth-related processes in neurons and synapses.

Several studies have shown an effect of $\mathrm{E}_{2}$ on BDNF and/or its message, which appears to vary depending upon the age of the organism, length of ovariectomy, $\mathrm{E}_{2}$ replacement regimens, and brain area [12-20]. The gene encoding BDNF contains a sequence similar to the canonical $\mathrm{E}_{2}$-response element found in $\mathrm{E}_{2}$-target genes [12]. Therefore, $\mathrm{E}_{2}$ actions on BDNF may result from a direct, genomic effect. On the other hand, $\mathrm{E}_{2}$ may modulate the expression of BDNF as a consequence of activation of the cAMP response element-binding protein (CREB) via protein kinases, such as protein kinase A (PKA), calcium/calmodulin kinase IV (CaMK IV), and mitogen activated protein kinase (MAPK) [21-23]. Phosphorylated CREB (pCREB) can form homo- or heterodimers with cAMP-responsive modulator protein (CREM) or activating transacting factor, and bind to CREB response element (CRE) sites of promotor regions of genes. Together with the appropriate co-activators, the complex can regulate transcription of CREB-related genes, such as BDNF [21-23], proenkephalin [24] and bcl-2 [25], which have growth-like or anti-apoptotic effects in the brain. BDNF can stimulate cellular growth and synaptic remodeling in relevant brain areas and, through these actions, may lead to altered behavioral output. Several reports have shown an effect of $E_{2}$ on CREB or pCREB, some of which indicate rapid, non-genomic actions of this steroid [26-32]. In a series of studies, we found that $E_{2}$ treatment to ovariectomized rats increases protein levels of CaMK IV, CREB and pCREB in amygdaloid structures [33, 34]. Immunoperoxidase labeling within the amygdala and hippocampus revealed an increase in pCREB immunoreactivity in subdivisions of the medial amygdala, as well as in CA1 and CA3 regions of the hippocampus [33]. In addition, $\mathrm{E}_{2}$ decreased immunolabeling for the phosphatase calcineurin in the medial and basomedial, but not central or basolateral, amygdala of ovariectomized rats [35]. Decreased protein levels of calcineurin may allow the persistence of $\mathrm{pCREB}$ which, in turn, may stabilize the pCREB/CREB-binding protein complex necessary for efficient CRE-regulated gene transcription [36].

Clinical studies indicate that $\mathrm{E}_{2}$ may play a role in emotional behaviors [37-42]. We have demonstrated an ameliorative effect of $E_{2}$ in the forced swim test, a test for the efficacy of antidepressants [43]. The CREB signaling pathway appears to be a target of antidepressant action [44] and is implicated in synaptic growth and plasticity [45-47]. BDNF has also been implicated as a player in antidepressant action [see for example 48-52 and review in 53], and recent studies have shown that single nucleotide polymorphisms of the $b d n f$ gene may be associated with affective [54], as well as cognitive [55] behaviors. However, there are no studies demonstrating an effect of $\mathrm{E}_{2}$ on both components of the CREB cascade and BDNF protein and mRNA in emotionally-relevant brain areas. We, therefore, investigated the effects of $E_{2}$ treatment (10 $\mu \mathrm{g} \mathrm{E}_{2}$ for 14 days) to ovariectomized rats on immunolabeling and mRNA levels of BDNF in amygdaloid and hippocampal brain structures. In order to better correlate the changes in BDNF expression with CREB signaling, we also examined the effects of $E_{2}$ treatment on levels of CaMK IV, CREB, and pCREB immunolabeling in brain structures of ovariectomized rats.

\section{Materials and Methods}

Adult, ovariectomized Sprague-Dawley rats (200-250 g) were purchased from Harlan (Madison, Wisc., USA). All rats were housed 2-3 per cage and adapted to a reverse light/dark cycle (lights on at 20:00 h) for 19 days, which also permitted clearance of endogenous estradiol levels [56]. Rat chow and water were available ad libitum. Animals were tested for completeness of ovariectomy by placing a male rat in a cage with each female for 6 consecutive days to determine the lordosis quotient (number of mounts/number of lordoses) [57]; none of the rats displayed lordosis. Rats were injected subcutaneously with $10 \mu \mathrm{g} 17 \beta$-estradiol $\left(\mathrm{E}_{2}\right)$ in $0.1 \mathrm{ml}$ sesame oil or the vehicle control between 09:00 and 10:00 h for 14 
days. Twenty-four hours after the last injection, the animals were perfused with fixative as described below. The injection dosages and protocols chosen were based on published data from our laboratory [see for example, $4,5,33-35,58$ ], as well as those of others [27], so as to optimize the detection of hormonal action on cellular responses and relate our finding to previously published biochemical, molecular, and immunocytochemical data on $E_{2}$ effects on the CREB signaling cascade [33-35]. Guidelines for the humane and proper treatment of animals were followed.

\section{Immunocytochemistry Protocol}

The protocol has been used previously [35, 59-63] and is briefly described as follows. Rats treated with $\mathrm{E}_{2}$ or vehicle were deeply anesthetized with Nembutal and transcardially perfused with $100 \mathrm{ml}$ of normal saline, followed by $300 \mathrm{ml}$ of 4\% paraformaldehyde in $0.1 M$ phosphate buffer. The brains were removed and postfixed for overnight in the same fixative before being transferred to 10,20 and $30 \%$ sucrose in $0.1 \mathrm{M}$ phosphate-buffered saline (PBS, $\mathrm{pH} 7.4$ ), at $4^{\circ} \mathrm{C}$. The brains were then frozen at $-80^{\circ} \mathrm{C}$. $20-\mu \mathrm{m}$ coronal sections were cut at identical bregma levels using a Paxino and Watson [64] atlas as reference through the medial, basomedial, central and basolateral amygdala and through the CA1, CA2, CA3 and hilus and dorsal and ventral dentate gyrus on a cryostat. Sections were processed for immunocytochemistry as described below.

Sections were washed with PBS and blocked for 30 min with RPMI 1640 (Gibco BRL), which we have found to be an effective blocker of non-specific binding for this procedure [61]. This step was followed by $10 \%$ normal serum (diluted in PBS containing 25\% Triton X-100) for $30 \mathrm{~min}$ at room temperature. Sections were then incubated with 1\% BSA (prepared in PBS containing 0.25\% Triton $\mathrm{X}-100$ ) for $30 \mathrm{~min}$ at room temperature. Sections were further incubated with the primary antibody [CaMK IV (Santa Cruz Biotechnology, Santa Cruz, Calif., USA) (dilution, 1:200); antibodies to CREB and pCREB (Upstate Biotechnology, Waltham, Mass., USA) (dilution, 1:500); antibodies to BDNF (Santa Cruz Biotechnology) (dilution, 1:200)] in 1\% BSA prepared in PBS containing $0.25 \%$ Triton $\mathrm{X}-100$ for $18 \mathrm{~h}$ at room temperature. The dilutions of the antibodies were based on those from previous publications [34, 59-61, 65]. The antibodies used here have been well characterized in our laboratory. Following washes with PBS and 1\% BSA in PBS, sections were incubated with 1-nm gold particles conjugated to the appropriate secondary antibody for $1 \mathrm{~h}$ at room temperature. For the negative control, the same protocol was used except that $1 \%$ BSA in PBS was substituted for the primary antibody. Sections were rinsed several times in $1 \%$ BSA, followed by rinses in doubledistilled water. Gold particles were then silver-enhanced (Ted Pella, Inc., Redding, Calif., USA) for 12-20 min and washed several times in double-distilled water. Sections were mounted on slides and examined under a light microscope.

Quantification of immunolabeled gold particles was performed with the Loats Image Analysis System connected to a light microscope that calculated the number of gold particles/100 $\mu^{2}$ area of defined amygdaloid or hippocampal structures at high magnification $(\times 100)$, as reported by us previously [34, 35, 59-61]. The threshold of each image was set up in two ways: one within the section itself; areas without labeling gave zero counts and then crossed check with negative sections. Three matching sections for each rat were used for analysis. Three randomly selected fields were chosen for each subnucleus examined of the amygdala or hippocampus.
Calculations were made from these fields from each section. Thus, from one rat, data were pooled from nine fields of three matching sections. For comparisons between $\mathrm{E}_{2}$-treated and control groups, data was analyzed using the non-parametric Mann-Whitney U-test, as in our previous immunogold studies [34, 35]. A value of $p<0.05$ was considered significant.

In situ PCR for BDNF mRNA Levels Measurement in Brain

Rat brain sections were used to determine the mRNA levels of BDNF using in situ RT-PCR as described by Pandey et al. [60, 61] and Zhang and Pandey [66]. We used the non-radioactive in situ method because it is more sensitive than standard in situ hybridization methods and the potential to increase the sensitivity is approximately eight times over conventional in situ hybridization methods [67]. 40- $\mu \mathrm{m}$ sections were cut on a cryostat and sections from each of two anterior-posterior [64] levels of interest as described above were processed for in situ RT-PCR as described below.

Sections were washed with PBS and incubated in proteinase $\mathrm{K}$ $(1 \mu \mathrm{g} / \mathrm{ml}$ in $1 \times$ PBS, $0.05 \%$ Triton $\mathrm{X}-100)$ for $15 \mathrm{~min}$ at $37^{\circ} \mathrm{C}$. The reaction was stopped by $0.1 M$ glycine for $20 \mathrm{~min}$. The sections were washed with $1 \times$ PBS and then subjected to DNase digestion solution $(2 \mu \mathrm{l}$ RNase inhibitor, $8 \mu \mathrm{l}$ water, $80 \mu \mathrm{l}$ RQ1RNase free DNase and $10 \mu 1$ DNase $10 \times$ buffer 1$)$ overnight (12-16 h) at room temperature.

Sections were washed with $1 \times$ PBS and transferred to $100-\mu 1$ RT reaction mixture containing Oligo d(T) (Applied Biosystems, Foster City, Calif., USA) and reverse transcribed for $30 \mathrm{~min}$ at $42^{\circ} \mathrm{C}$. For negative control sections, reverse transcriptase was replaced by DEPC-treated water. The sections were transferred to PCR reaction mixtures containing DIG-11-dUTP instead of dUTP. PCR was performed with $0.5 \mu \mathrm{l}$ Taq DNA polymerase enzyme and $1 \mu \mathrm{l}(36-37 \mathrm{pmol})$ each of BDNF primer. Primers were as follows: forward primer: 5'TAACGGCGGCAGACAAAAAGACT3'; backward primer: 5'GTGTCTATCCTTATGAATCGCCAA3'. Following PCR, sections were mounted on slides and BDNF-positive cell bodies were detected by using alkaline phosphate-conjugated anti-digoxigenin antibody and subsequent staining of the complex with specific substrate NBT/BCIP (Roche Molecular Biochemical, Mannheim, Germany). The linearity of the reaction was established first by fixing the RNA and increasing the amplification of the DNA. We used the amplification cycle in the linear range, a procedure we have used in our previous publications $[60,61,66]$.

The optical density (OD) of positive areas containing cell bodies was calculated with an image analyzer (Loats Associates). The in situ PCR threshold was set up using negative sections. That is, the OD of negative sections has been subtracted from the OD of the area containing positive cell nuclei. With each amygdaloid or hippocampal subregion analyzed, three randomly selected areas were subject to analysis. The OD of positive cell bodies was calculated by the image analysis system itself, and then values were averaged for each rat. The mRNA results were represented as mean OD/100 pixels area. 
Fig. 1. a Photomicrographs of BDNF immunolabeling in amygdaloid structures from ovariectomized $(\mathrm{OVX})$ estrogen $\left(\mathrm{E}_{2}\right)$ and vehicle-treated rats. The top panel shows light micrographs at low magnification of BDNF immunogold labeling in the central amygdala $(\mathrm{CeA})$ and medial amygdala $(\mathrm{MeA})$ from $\mathrm{E}_{2}$ - and vehicle-treated rats. Scale bar $=400 \mu \mathrm{m}$. Photomicrographs from the $\mathrm{CeA}$ (center panel) and MeA (bottom panel) from $\mathrm{E}_{2}$ - and vehicle-treated rats are shown at higher magnification. Scale bar $=20 \mu \mathrm{m}$.

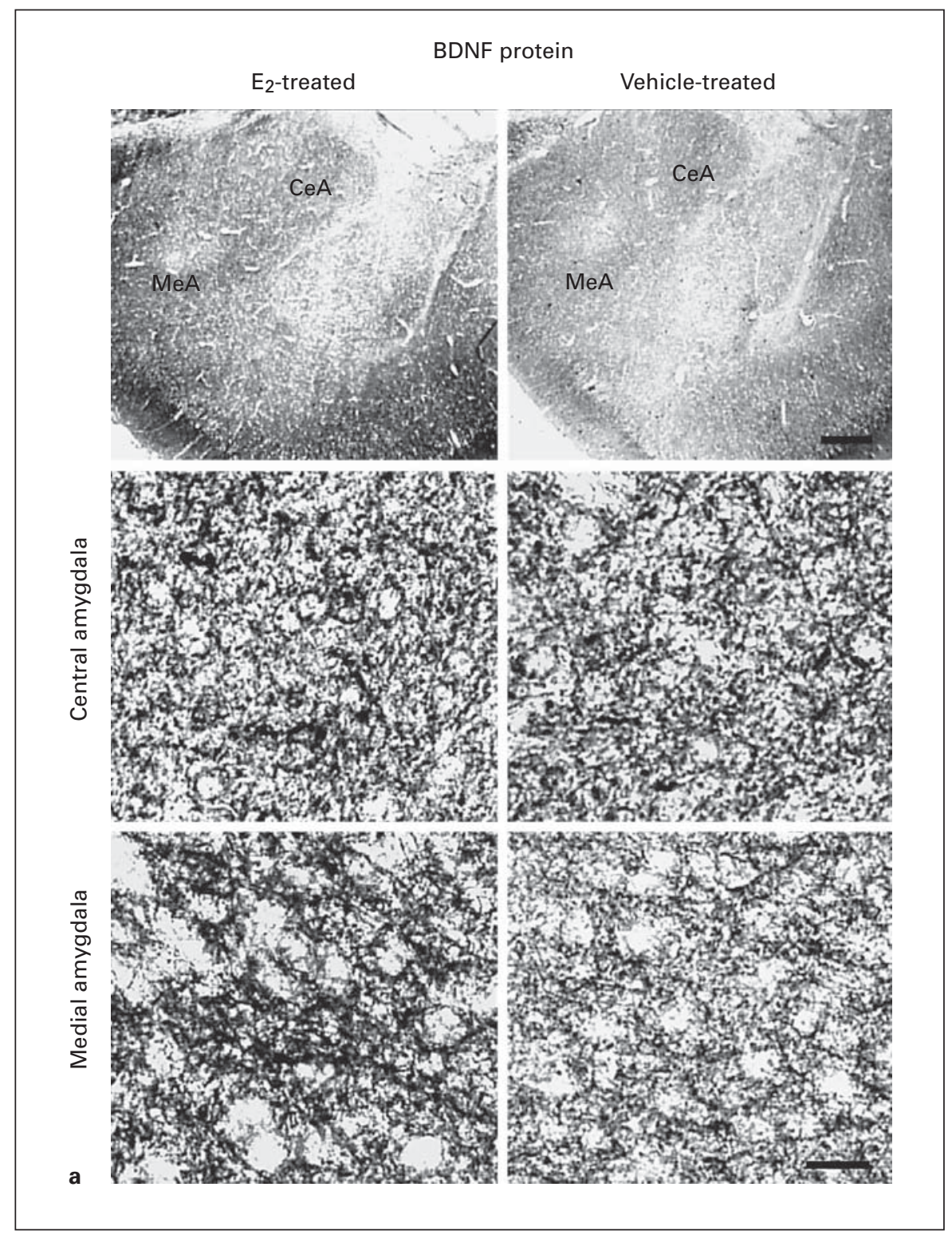

\section{Results}

\section{Effects of Estradiol Benzoate Treatment on BDNF}

Immunolabeling and Levels of BDNF $m R N A$

Signal in the Amygdala and Hippocampus of

\section{Ovariectomized Rats}

We used immunogold labeling to determine the localization of BDNF protein within the amygdaloid and hippocampal structures. Immunogold labeling for BDNF was detected in cell bodies and neuronal fibers, as reported previously [60] (fig. 1a). $E_{2}$ treatment of ovariectomized rats resulted in an increase in immunogold labeling in the medial and basomedial, but not central or basolateral, amygdala of ovariectomized rats. Using the central and medial amygdala as representative brain areas, figure 1a shows low and high magnification light micrographs illustrating differences in gold immunolabeling in these two brain regions. Quantification of the data for various structures of the amygdala and hippocampus is shown in the graph in figure 1b. A significant increase in the number of immunogold particles/100 $\mu^{2}$ is seen in the medial $(238 \pm 5.66$ vs. $191 \pm 4.83, \mathrm{p}<0.01)$ and basomedial $(227 \pm 5.12$ vs. $189 \pm 6.19, \mathrm{p}<0.01)$, but not central or basolateral, amygdala of the $\mathrm{E}_{2}$-treated group com- 
Fig. 1. b Quantitation of BDNF immunogold labeling (number of immunogold particles per $100 \mu \mathrm{m}^{2}$ area) shows that $\mathrm{E}_{2}$ treatment significantly increases levels of BDNF immunolabeling in specific subdivisions of the amygdala and hippocampus. A significant increase in immunogold labeling is seen in the medial $(\mathrm{MeA})(\mathrm{p}<0.01)$ and basomedial (BMA) $(\mathrm{p}<0.01)$, but not central (CeA) or basolateral (BLA), amygdala of the $E_{2}$-treated group $(n=6)$ compared to the OVX control animals $(n=6)$. A significant increase in levels of BDNF immunolabeling is seen in the CA1 $(p<0.001)$ and CA3 $(p<0.001)$ regions of the hippocampus, but not in the CA2, dorsal dentate gyrus (DDG), hilus, or ventral dentate gyrus (VDG) of the $E_{2}$-treated group $(n=6)$ compared to the OVX control $(n=6)$ animals. Values are the mean \pm SEM. * Significantly different from vehicle-treated rats.
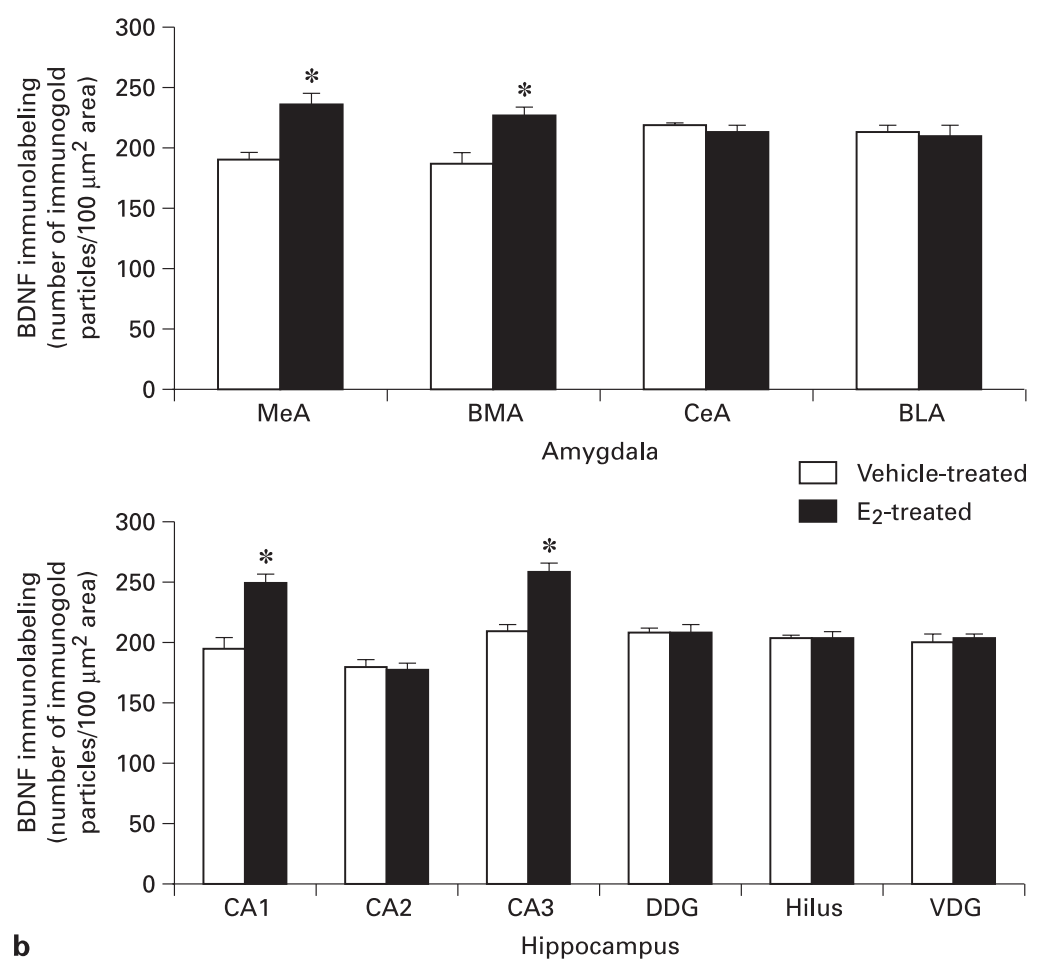

pared to the ovariectomized control animals. Immunogold labeling for BDNF was detected in the cell bodies and neuronal fibres of hippocampal cells (micrograph not shown). A quantitative analysis of the levels of BDNF immunolabeling in subdivisions of the hippocampus is shown in the graph in figure 1b. A significant increase in the immunolabeling (number of gold particles $/ 100 \mu \mathrm{m}^{2}$ of area) is seen in the CA1 $(250 \pm 8.1$ vs. $195 \pm 8.03$, $\mathrm{p}<0.001)$ and CA3 $(261 \pm 3.07$ vs. $210 \pm 6.73, \mathrm{p}<$ 0.001 ) regions of the hippocampus, but not in the CA2, dorsal dentate gyrus (DDG), hilus, or ventral dentate gyrus (VDG) of the $\mathrm{E}_{2}$-treated group compared to the ovariectomized control animals.

To determine the effect of $E_{2}$ on mRNA levels of BDNF in the amygdala and hippocampus, we used in situ RT-PCR. The positive cell bodies in the amygdaloid structures showing the signal for levels of BDNF mRNA are shown in figure $2 \mathrm{a} . \mathrm{E}_{2}$ treatment of ovariectomized rats resulted in an increase in the levels of BDNF mRNA in the medial and basomedial, but not central or basolateral, amygdala. These findings are illustrated in figure 2a, which show low and high magnification light micrographs of the medial and central amygdala following $\mathrm{E}_{2}$ or ve- hicle treatment to ovariectomized rats as examples. Quantitative analysis of the mRNA levels of BDNF in each of the aforementioned amygdaloid areas is shown in figure $2 b$. A significant increase in the mean mRNA levels $(\mathrm{OD} / 100$ pixels area $)$ is seen in the medial $(11.6 \pm 0.54$ vs. $8.9 \pm 0.25, \mathrm{p}<0.01)$ and basomedial $(11.1 \pm 0.57$ vs. $8.7 \pm 0.28, \mathrm{p}<0.01)$, but not central or basolateral, amygdala of the $E_{2}$-treated compared to the control group.

A quantitative analysis of mRNA levels for BDNF in each of the hippocampal areas is shown in the graph in figure $2 \mathrm{~b}$. $\mathrm{E}_{2}$ administration to ovariectomized rats resulted in an increase in mRNA levels of BDNF in the CA1 and CA3 regions of the hippocampus, but not in the CA2 region or in any of the subdivisions of the dorsal dentate gyrus (DDG), hilus, or ventral dentate gyrus (VDG) of $E_{2}$-treated group compared to ovariectomized controls. A significant increase in the mean levels of signal for BDNF mRNA (OD/100 pixels/area) is seen in the CA1 $(12.4 \pm 1.15$ vs. $8.9 \pm 0.88, \mathrm{p}<0.001)$ and CA3 $(14.1 \pm 1.16$ vs. $10.1 \pm 0.79, \mathrm{p}<0.001)$ regions, but not $\mathrm{CA} 2$, DDG, hilus, or VDG of the $\mathrm{E}_{2}$-treated group compared to ovariectomized controls. 
Fig. 2. a Photomicrographs of $B D N F$ mRNA signal (in situ PCR) in amygdaloid structures from ovariectomized (OVX) estrogen $\left(\mathrm{E}_{2}\right)$ - and vehicle-treated rats. The top panel shows light micrographs at low magnification of the levels of mRNA for BDNF in the central amygdala (CeA) and medial amygdala $(\mathrm{MeA})$ from $\mathrm{E}_{2}$ - and vehicle-treated rats. Scale bar $=400 \mu \mathrm{m}$. Photomicrographs from the CeA (middle panel) and MeA (bottom panel) amygdala from $E_{2^{-}}$and vehicle-treated rats shows the BDNF mRNA signal at higher magnification. Scale bar $=30 \mu \mathrm{m}$.

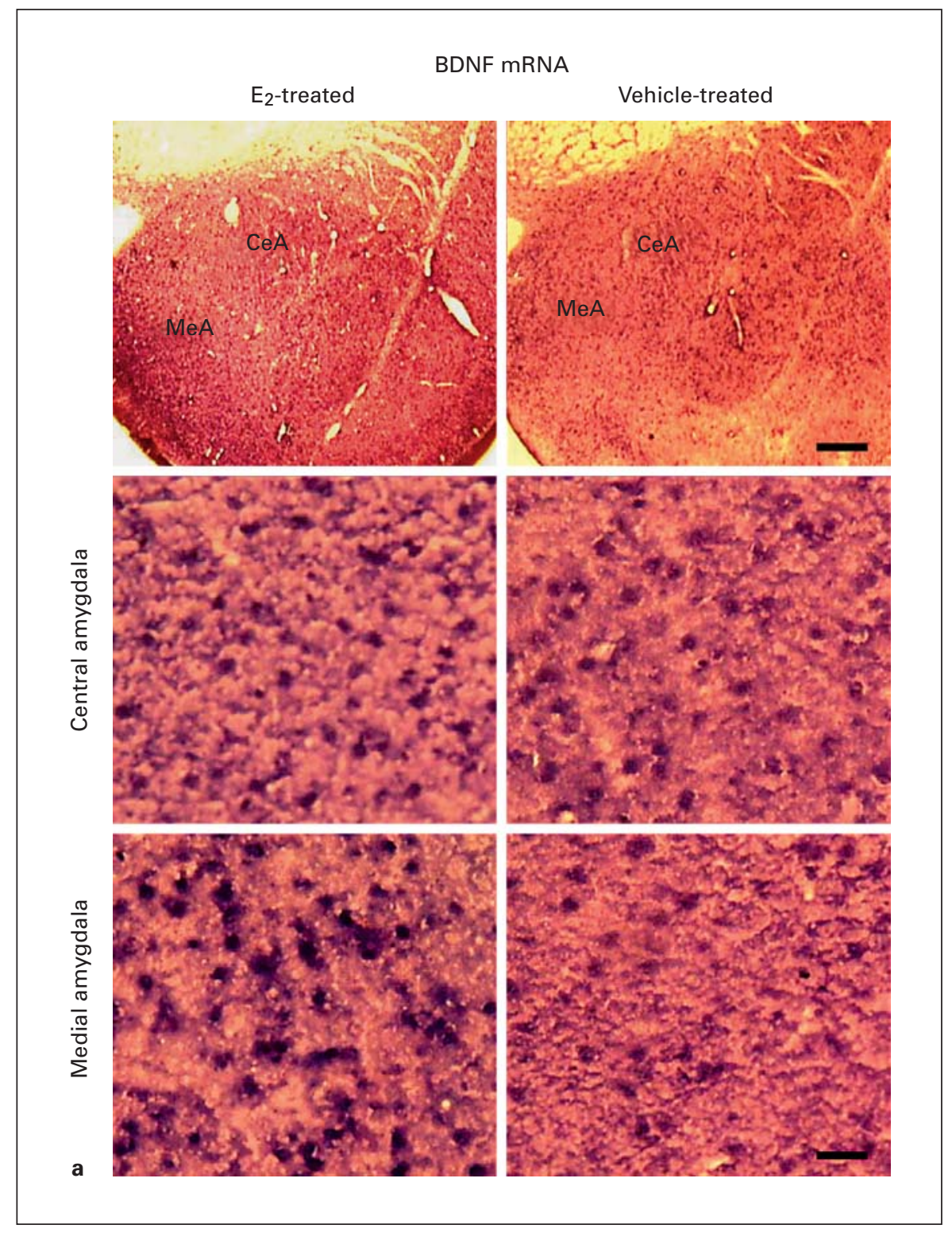

\section{Effects of Estradiol Benzoate Treatment on}

CaMK IV Immunolabeling in the Hippocampus of

\section{Ovariectomized Rats}

Our previous studies indicated that administration of the $\mathrm{E}_{2}$ regimen used in the present study had no effect on the immunoreactivity as seen with Western blot analysis of the $\alpha$-isoform of the PKA catalytic subunit (PKA- $\alpha$ ) or levels of PKA activity under basal or cAMP-stimulated conditions [33]. However, this $\mathrm{E}_{2}$ regimen increases the protein levels of CaMK IV in the nuclear, but not cytoplasmic or membrane fraction of the amygdala of ovariectomized rats [34], as seen with Western blot analysis; an $E_{2}$-induced increase in immunogold labeling was also seen in the medial and basomedial, but not central or basolateral, amygdala of ovariectomized rats [34]. CaMK IV is also a likely candidate for CREB phosphorylation in the hippocampus because CREB is a major substrate for CaMK IV and CaMK IV has been implicated in hippocampal CA1 function $[68,69]$. CaMK IV is also the major CREB kinase in activity-dependent neuronal gene expression [36, 70, 71]. In addition, it has been shown that female fertility is reduced in mice lacking CaMK IV [72]. Moreover, there is a growing literature for the role of $\mathrm{E}_{2}$ in calcium signaling events, including dendritic spine 
Fig. 2. b Quantitation of the BDNF mRNA signal shows a significant increase in levels of BDNF mRNA signal in the medial (MeA) $(\mathrm{p}<0.01)$ and basomedial (BMA) $(\mathrm{p}<$ $0.01)$, but not central (CeA) or basolateral (BLA), amygdala of the $E_{2}$-treated $(n=5)$ compared to the control $(n=5)$ group. A significant increase in levels of BDNF mRNA is seen in the CA1 $(p<0.001)$ and CA3 ( $p<0.001)$ regions of the hippocampus, but not CA2, dorsal dentate gyrus (DDG), hilus, or ventral dentate gyrus (VDG) of $E_{2}$-treated group compared to OVX controls. Values are the mean \pm SEM and are represented as the mean OD/100 pixels of area. * Significantly different from vehicle-treated rats.
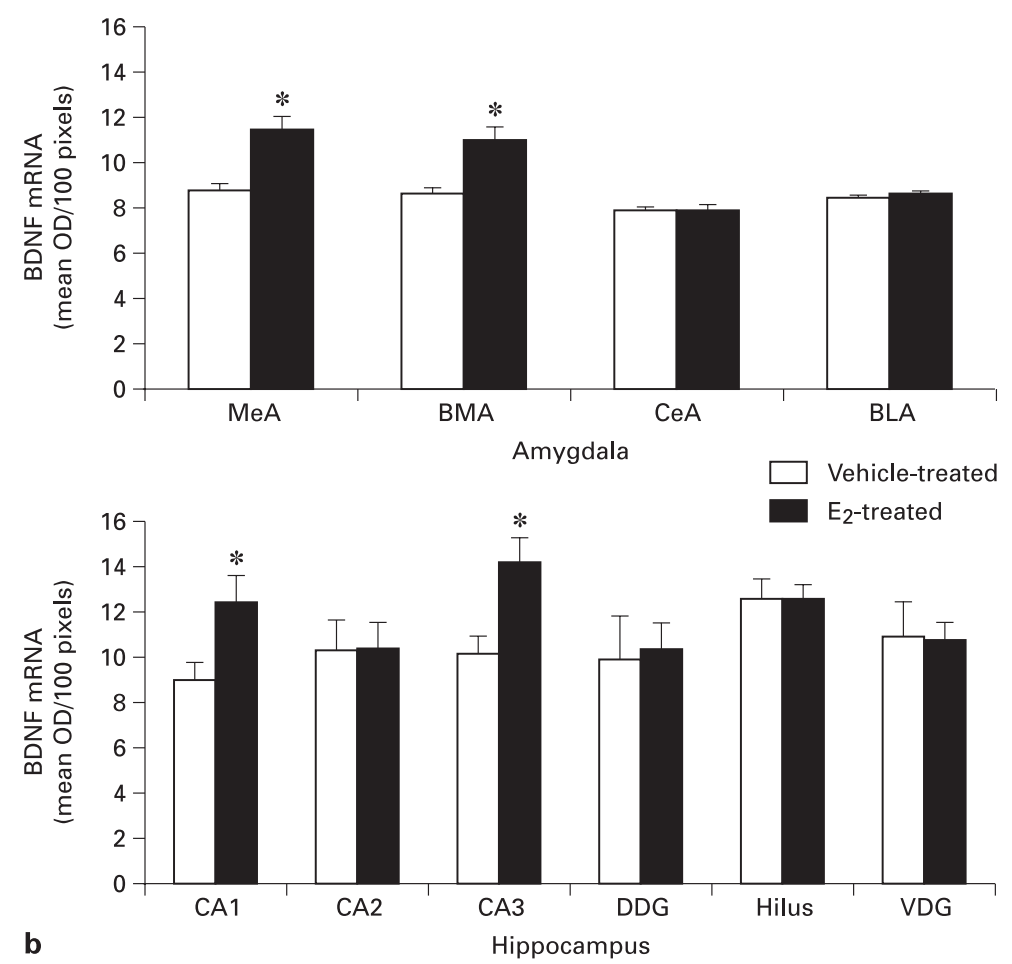

growth [see discussion in 73]. Also, a significant increase in total CaMK IV protein was seen in the hippocampus following chronic treatment with the antidepressant fluoxetine [74]. We extended the aforementioned CaMK IV studies in the amygdala [34] and examined the effects of $\mathrm{E}_{2}$ treatment to ovariectomized rats on immunogold labeling of CaMK IV in hippocampal structures. Prior to the present study, there was no data on the effect of $E_{2}$ on CaMK IV in the various hippocampal structures.

Figure 3a shows representative areas of brain sections labeled for CaMK IV in the CA1 and CA3 regions of the hippocampus of ovariectomized $\mathrm{E}_{2}$ - and vehicle-treated animals at high magnification. We found a significant increase in immunogold labeling for CaMK IV (immunogold particles $/ 100 \mu \mathrm{m}^{2}$ area) in the CA1 (98 \pm 3.53 vs. $78 \pm 3.01, \mathrm{p}<0.01)$ and CA3 $(101 \pm 5.62$ vs. $78 \pm 3.01$, $\mathrm{p}<0.01$ ) regions of the hippocampus, but not CA2, DDG, hilus or VDG of the $\mathrm{E}_{2}$-treated group compared to the control animals (fig. 3b).

\section{Effects of Estradiol Benzoate Treatment on}

Immunolabeling for CREB and $p C R E B$ in the

Amygdala and Hippocampus of Ovariectomized Rats

$\mathrm{E}_{2}$ treatment increased the levels of immunogold labeling for CREB in the medial and basomedial, but not central or basolateral, subdivisions of the amygdala compared to the ovariectomized controls. Figure 4a shows representative low and high magnifications of sections labeled for CREB from the medial and central amygdala of $E_{2}$-and vehicle-treated ovariectomized rats. The graphs in figure $4 \mathrm{~b}$ show a significant increase in CREB immunogold labeling (number of gold particles/100 $\mu \mathrm{m}^{2}$ ) in the medial $(120 \pm 4.47$ vs. $96 \pm 5.47, \mathrm{p}<0.001)$ and basomedial $(114 \pm 4.18$ vs. $93 \pm 3.72, p<0.001)$, but not central or basolateral, amygdala of the $\mathrm{E}_{2}$-treated group compared to the ovariectomized controls. In contrast, there was no change in CREB immunogold labeling, in any of the subregions of the hippocampus (CA1, CA2, $\mathrm{CA} 3$, or dentate gyrus) after 14 days treatment with $\mathrm{E}_{2}$ (fig. 4b).

A significant $\mathrm{E}_{2}$-induced increase in immunogold labeling of pCREB was seen in the medial and basomedial, 
Fig. 3. a Photomicrographs of CaMK IV immunolabeling in the hippocampus of ovariectomized (OVX) estrogen $\left(\mathrm{E}_{2}\right)$ - and vehicle-treated rats. The top panel shows light micrographs at high magnification of CaMK IV immunogold labeling in the CA1 and CA3 regions of the hippocampus from $\mathrm{E}_{2}$ - and vehicle-treated rats. Scale bar = $30 \mu \mathrm{m}$. b Quantitation of CaMK IV immunogold labeling (number of immunogold particles per $100 \mu \mathrm{m}^{2}$ area) shows that $E_{2}$ treatment significantly increases levels of CaMK IV immunolabeling in specific subdivisions of the hippocampus. A significant increase in immunolabeling is seen in the CA1 $(p<0.001)$ and CA3 $(p<0.001)$ regions of the hippocampus, but not CA2, dorsal dentate gyrus (DDG), hilus or ventral dentate gyrus (VDG) of the $E_{2}-(n=6)$ treated group compared to the OVX control animals $(n=6)$. Values are the mean \pm SEM. * Significantly different from vehicletreated rats.
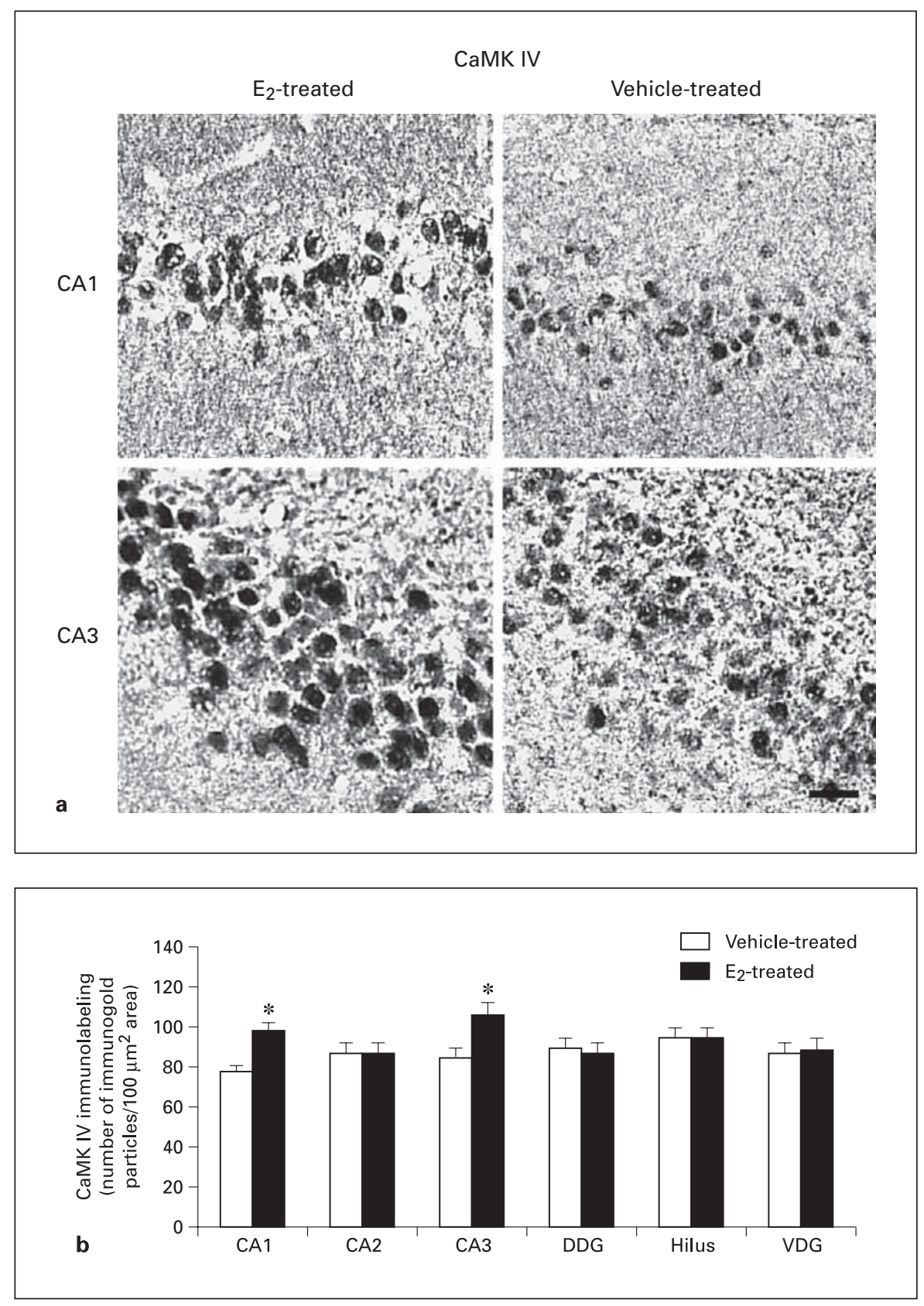

but not central or basolateral, amygdala of the $\mathrm{E}_{2}$-treated group compared to the ovariectomized control animals. Figure 5a shows low and high magnification micrographs of sections labeled with pCREB from the central and medial amygdala from $\mathrm{E}_{2}$ - and vehicle-treated rats as examples (fig. 5a). Quantification of the data indicates a significant increase in the number of gold particles/ $100 \mu^{2}$ in the medial $(99 \pm 3.26$ vs. $81 \pm 4.58, \mathrm{p}<$ $0.001)$ and basomedial $(102 \pm 6.50$ vs. $82 \pm 4.58, \mathrm{p}<$
0.01 ), but not central or basolateral, amygdala of the $\mathrm{E}_{2^{-}}$ treated group compared to the ovariectomized control animals (fig. 5c).

Figure $5 \mathrm{~b}$ shows representative areas of brain sections labeled for pCREB in the CA1 and CA3 regions of the hippocampus of ovariectomized $\mathrm{E}_{2}$ - and vehicle-treated animals at high magnification. A significant increase in immunogold labeling for pCREB (number of gold particles $/ 100 \mu \mathrm{m}^{2}$ area $)$ is seen in the CA1 (112 \pm 5.48 vs. 87 
Fig. 4. a Photomicrographs of CREB immunolabeling in amygdaloid structures from ovariectomized $(\mathrm{OVX})$ estrogen $\left(\mathrm{E}_{2}\right)$ and vehicle-treated rats. The top panel shows light micrographs at low magnification of CREB immunogold labeling in the central amygdala (CeA) and medial amygdala $(\mathrm{MeA})$ from $\mathrm{E}_{2}$ - and vehicle-treated rats. Scale bar $=400 \mu \mathrm{m}$. Photomicrographs from the central (center panel) and medial (bottom panel) amygdala from $\mathrm{E}_{2}$ - and vehicle-treated rats are shown at higher magnification. Scale bar $=30 \mu \mathrm{m}$.

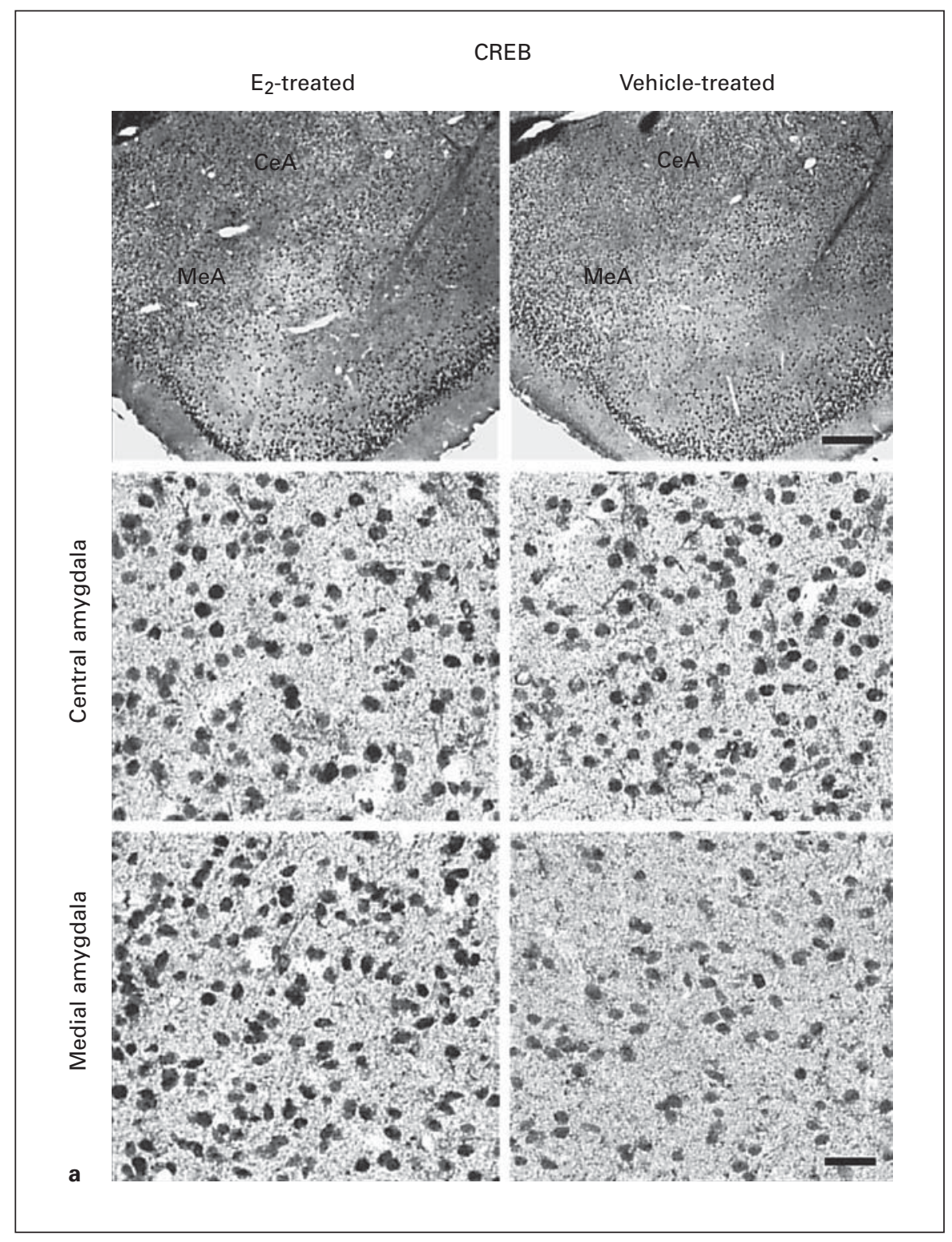

$\pm 3.40, \mathrm{p}<0.0001)$ and CA3 $(120 \pm 5.54$ vs. $92 \pm 3.86$, $\mathrm{p}<0.0001)$ regions of the hippocampus, but not CA2, DDG, hilus or VDG of the $\mathrm{E}_{2}$-treated group compared to the control animals (fig. 5c). These results are consistent with our previous study using immunoperoxidase (DAB) labeling to demonstrate an $\mathrm{E}_{2}$-induced increase in $\mathrm{pCREB}$ immunolabeling in the medial amygdala, and CA1 and CA3 regions, but not dentate gyrus, of the hippocampus of ovariectomized rats [33].

\section{Discussion}

Our data indicate that the same dose and time regimen of $E_{2}$ alters levels of immunolabeling for components of the CREB signaling pathway and the CREB-related gene product BDNF and the levels of mRNA for BDNF. Of particular importance is the observation of neuroanatomical heterogeneity of the $\mathrm{E}_{2}$ effect within the amygdala and hippocampus. Except for the lack of effect of $E_{2}$ on CREB immunolabeling in any of the subregions of the hippocampus, $\mathrm{E}_{2}$ increased levels of CaMK IV [34], pCREB and BDNF immunolabeling and mRNA levels 
Fig. 4. b Quantitation of CREB immunogold labeling (number of immunogold particles per $100 \mu \mathrm{m}^{2}$ area) shows that $\mathrm{E}_{2}$ treatment significantly increases levels of CREB immunolabeling in specific subdivisions of the amygdala, but not in any of the subdivisions of the hippocampus. A significant increase in the number of gold particles/ $100 \mu \mathrm{m}^{2}$ is seen in the medial $(\mathrm{MeA})(\mathrm{p}<$ $0.001)$ and basomedial (BMA) $(p<0.001)$, but not central (CeA) or basolateral (BLA), amygdala of the $E_{2}$-treated group $(n=6)$ compared to the OVX control $(n=6)$ animals. No differences were seen in the number of gold particles $/ 100 \mu \mathrm{m}^{2}$ in the CA1, $\mathrm{CA} 2$, or CA3 regions, or dorsal dentate gyrus (DDG), hilus or ventral dentate gyrus (VDG) of the hippocampus between the $\mathrm{E}_{2}$-treated group and OVX control animals. Values are the mean \pm SEM. * Significantly different from vehicle-treated rats.
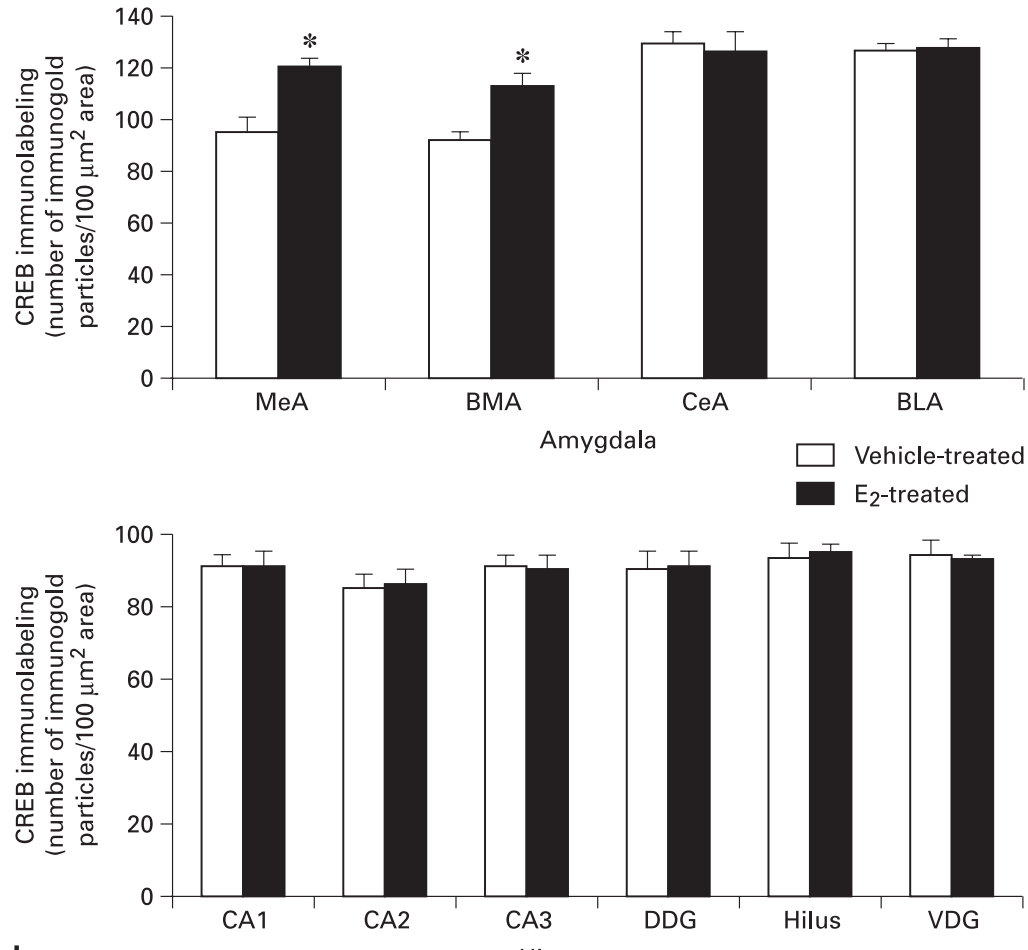

b

Hippocampus of BDNF in the medial and basomedial amygdala and $\mathrm{CA} 1$ and $\mathrm{CA} 3$ regions of the hippocampus. The $\mathrm{E}_{2}$-induced increase in pCREB immunolabeling seen in the medial and basomedial subdivisions of the amygdala may be due, in part, to increased CREB protein expression, as well as CREB phosphorylation. In the CA1 and CA3 regions of the hippocampus, on the other hand, the $\mathrm{E}_{2}$-induced increase in $\mathrm{pCREB}$ immunolabeling may not involve an increase in CREB protein, but only an increase in CREB phosphorylation.

In the present study, levels of pCREB immunolabeling persisted during the 2 weeks of $\mathrm{E}_{2}$ treatment. The persistence of pCREB immunolabeling may be due to $\mathrm{E}_{2}$ influences on CaMK IV [34] and/or CREB depending upon the neurocircuitry examined. Alternatively, $\mathrm{E}_{2}$ may alter levels or activity of phosphatases, such as calcineurin, which regulate CREB phosphorylation. Levels of calcineurin mRNA in the ventromedial hypothalamus are significantly lower during proestrus (when $\mathrm{E}_{2}$ levels are high) than during diestrus (when $E_{2}$ levels are low) [75] and $E_{2}$ decreased calcineurin and PP1 activity in the hippocampus [76]. We have recently shown that a similar dose par- adigm of $\mathrm{E}_{2}$ decreased calcineurin immunolabeling in the medial and basomedial amygdala and CA1 regions of the hippocampus [35]. These results suggest the possibility that $\mathrm{E}_{2}$ action on calcineurin may, therefore, contribute to the increased levels of pCREB immunolabeling in the specific neurocircuitry of amygdala and hippocampus of $\mathrm{E}_{2}$-treated animals.

Our present studies are consistent with other biochemical and molecular studies showing changes in components of the CREB signaling pathway. Our biochemical data show, using the identical $\mathrm{E}_{2}$ dose and time regimen as that used in the present study, an $\mathrm{E}_{2}$-induced increase in CaMK IV [34], and pCREB and CREB [33] in the amygdala using Western blot analysis. However, in that study, because of the amount of tissue required for the analysis, we were only able to analyze whole amygdala, and not specific subnuclei. Moreover, using the identical $\mathrm{E}_{2}$ dose and time regimen as that used in the present study, we also demonstrated an $\mathrm{E}_{2}$-induced increase in CRE-DNA binding in whole amygdala using electrophoretic gel-mobility shift assay [33]. Furthermore, our present results are consistent with our immunoperoxidase 
Fig. 5. a Photomicrographs of $\mathrm{pCREB}$ immunolabeling in amygdaloid structures from ovariectomized $(\mathrm{OVX})$ estrogen $\left(\mathrm{E}_{2}\right)$ and vehicle-treated rats. The top panel shows light micrographs at low magnification of pCREB immunogold labeling in the central amygdala (CeA) and medial amygdala $(\mathrm{MeA})$ from $\mathrm{E}_{2}$ - and vehicle-treated rats. Scale bar $=400 \mu \mathrm{m}$. Photomicrographs from the CeA (center panel) and MeA (bottom panel) amygdala from $\mathrm{E}_{2}$ - and vehicletreated rats at higher magnification. Scale bar $=30 \mu \mathrm{m}$.

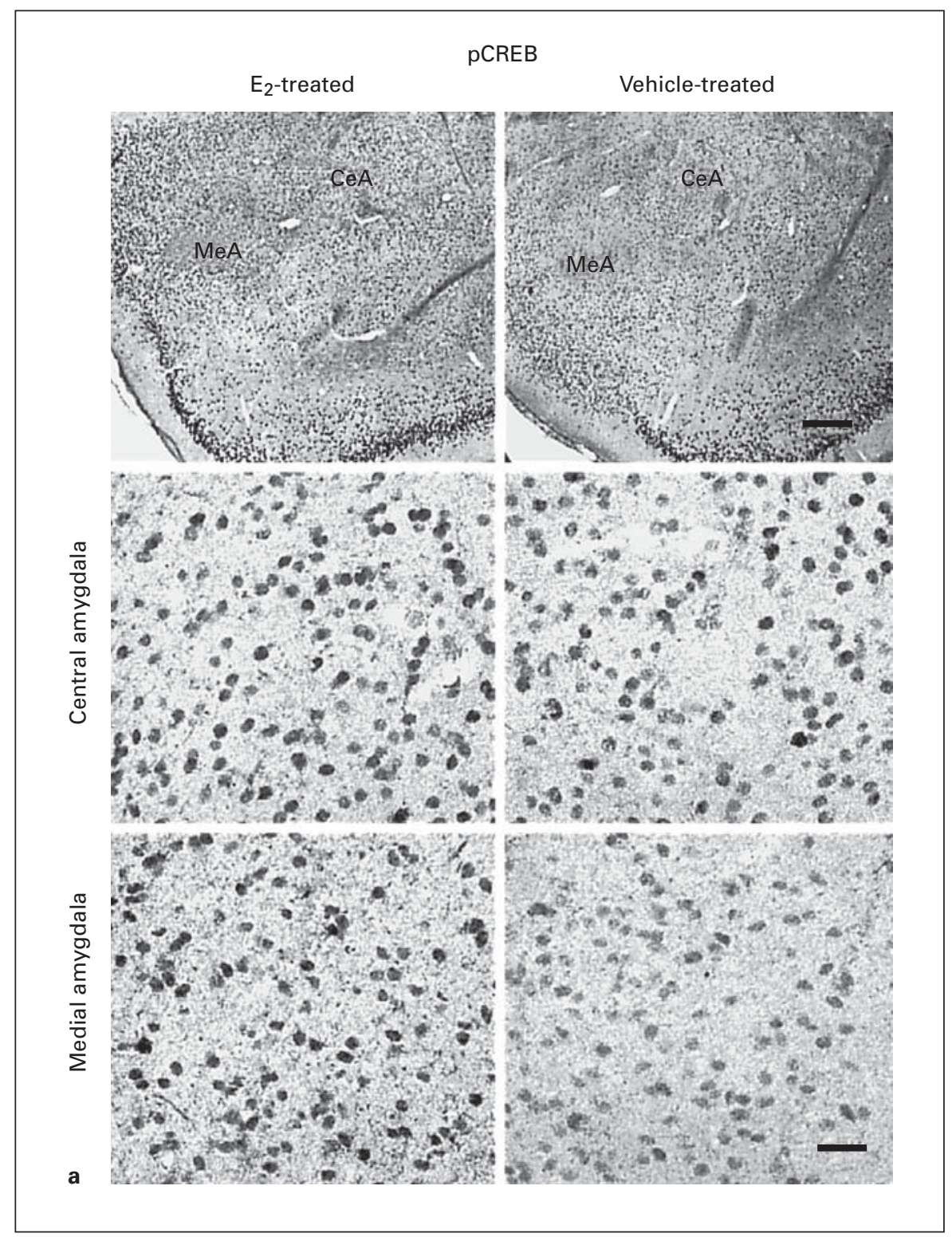

studies showing an $\mathrm{E}_{2}$-induced increase in the number of cells labeled with pCREB in the medial, but not central, amygdala, and CA1 and CA3 regions, but not hilus or dentate gyrus, of the hippocampus [33]. These results indicate that by various biochemical and histochemical approaches, we have achieved results consistent with those using immunogold labeling.

\section{Neuroanatomical Specificity of the $E_{2}$ Effect}

$\mathrm{E}_{2}$-induced alterations in levels of BDNF immunolabeling and mRNA were seen in specific brain structures within the amygdala and hippocampus. In the amygdala, changes in the parameters examined occurred specifically in the medial and basomedial, but not central or basolateral, amygdala. The amygdala consists of separate nuclei, which may play distinct roles in regulating different aspects of integrated emotional responses [77]. Some areas, such as the medial, central and basolateral amygdala, are associated with fear and anxiety [for discussion, see 78], as well as LTP [78]. In the basolateral amygdala, for example, $\mathrm{E}_{2}$ has been shown to decrease neuronal excitability [see 78, 79], probably via GABAergic mechanisms [78]. The central amygdala also mediates anxiety and fear behavior [for review, see 80, 81] and aggressive and de- 
Fig. 5. b Photomicrographs of pCREB immunolabeling from the CA1 and CA3 regions of the hippocampus from OVX estrogen $\left(E_{2}\right)$ - and vehicle-treated rats at high magnification. Scale bar $=30 \mu \mathrm{m}$. c Quantitation of pCREB immunogold labeling (number of immunogold particles per $100 \mu \mathrm{m}^{2}$ area) shows that $E_{2}$ treatment significantly increases levels of pCREB immunolabeling in specific subdivisions of the amygdala and hippocampus. A significant increase in pCREB immunogold labeling is seen in the medial $(\mathrm{MeA})(\mathrm{p}<0.001)$ and basomedial (BMA) $(\mathrm{p}<0.01)$, but not central (CeA) or basolateral (BLA), amygdala of the $E_{2}$-treated group compared to the OVX control animals. A significant increase in immunolabeling is seen in the CA1 $(p<0.0001)$ and CA3 $(p<0.0001)$ regions of the hippocampus, but not CA2, dorsal dentate gyrus (DDG), hilus or ventral dentate gyrus (VDG) of the $\mathrm{E}_{2}$-treated group $(n=6)$ compared to the OVX control $(\mathrm{n}=6)$ animals. Values are the mean \pm SEM. * Significantly different from vehicletreated rats.

Estrogen Effects on BDNF and CREB in the Limbic System
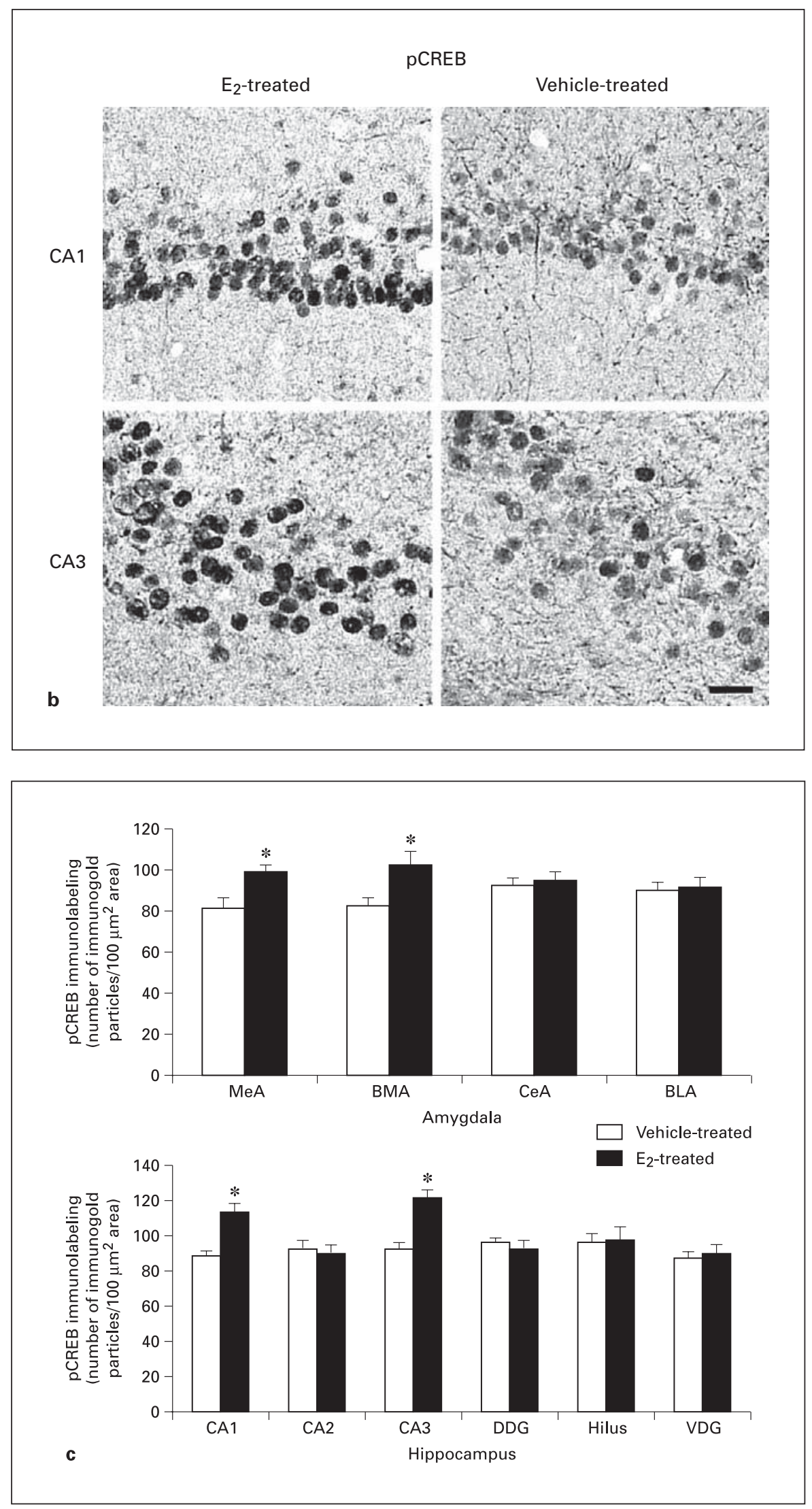

Neuroendocrinology 2005;81:294-310 
fensive behavior [81]. However, despite the presence of mRNAs for ER $\alpha$ [82] and ER $\beta$ [83, see also 84 for review] in the central amygdala, mRNA for ER $\alpha$ in the lateral, but not basal, amygdala [see 83 for review], and ER $\beta$ mRNA in the basolateral amygdala [85, but see also 84], we found no effect on BDNF immunolabeling or mRNA nor immunolabeling for the components of the CREB signaling pathway in these regions with our $\mathrm{E}_{2}$ regimen in the present study. We cannot, however, rule out a local effect, where $\mathrm{E}_{2}$ binding in the basolateral and/or central amygdala may have affected the CREB signaling pathway in the medial amygdala. Both ER $\alpha$ and ER $\beta$ are expressed in the medial amygdala of rat brain $[83,86]$ and these isoforms are also co-expressed in a large majority of neurons in this region [86]. Others have found that increases in some components of the CREB signaling pathway in some brain regions may not be associated with positive behavior [87-90]; however, those observations depend upon the specific neuroanatomical site, age of the animal, particular behavioral test, and timing of protein expression. Scharfman and MacLusky [2] note that $E_{2}$ and BDNF both have similar and dissimilar actions, which can be extensive and complex due to differences in experimental conditions, as well as other as yet unknown variables [2].

In the present study, we found a consistently positive effect on immunolabeling for CREB, pCREB and BDNF and BDNF mRNA in the medial and basomedial nuclei of the amygdala. Previously, we found that $\mathrm{E}_{2}$ increased the levels of CaMK IV in these nuclei of amygdala [34]. The medial amygdala consists of four subnuclei and has been implicated in a variety of functions, including interpretation of sensory information, social and reproductive behaviors, and the interpretation of emotionally-loaded stimuli [see discussion in 9]. The medial amygdala contains both ER subtypes [83], their specific distribution and quantities varying with the particular medial amygdaloid subnucleus [9]. Frye and Walf [91] have recently shown effects of systemic and/or intra-amygdala (i.e., medial amygdala) $E_{2}$, progesterone and/or $E_{2}$ plus progesterone on a variety of behaviors relevant to anxiety, fear and pain. Krężel et al. [78] have shown that ER $\beta$-deficient female mice display increased anxiety and reduced threshold for the induction of synaptic plasticity in the basolateral amygdala. In addition, there was a concomitant increase in immunolabeling for 5-hydroxytryptamine ${ }_{1 \mathrm{~A}}$ $\left(5-\mathrm{HT}_{1 \mathrm{~A}}\right)$ in the medial amygdala, suggesting that a local increase in expression of this receptor may contribute to these alterations in the basolateral amygdala [78].
The hippocampus plays a central role in cognition and affect and CREB signaling may also be involved. Some of the functional consequences of $\mathrm{E}_{2}, \mathrm{CREB}$ signaling and increased BDNF impact dendritic spine growth and plasticity in the CA1 region of the hippocampus [for reviews, see 1,2$]$. In terms of structural effects, components of the CREB signaling pathway, including CaMK IV, have been implicated in synaptic growth and/or remodeling [4547]. In terms of function, Marie et al. [47] showed that acute expression of active CaMK IV or CREB in CA1 pyramidal cells resulted in an enhancement of NMDAreceptor-mediated synaptic responses and LTP. These data were coincident with electrophysiological and structural alterations in accordance with the generation of 'silent synapses,' which permit additional experience-dependent changes in neural circuits. These adaptations may be necessary for the consolidation of long-term synaptic plasticity and memories.

\section{Effects of $E_{2}$ on Levels of BDNF Immunolabeling and Levels of $m R N A$ for $B D N F$}

The effects of $E_{2}$ on levels of BDNF mRNA are well documented [12-20]. However, disparities in hippocampal or amygdaloid responses to $E_{2}$ may be due to differences in $\mathrm{E}_{2}$ regimens (acute or chronic), modes of delivery (injections vs. pellets), length of time ovariectomized (acute vs. chronic), age of the animal when $\mathrm{E}_{2}$ replacement begins (young adult vs. old) and organism (strain of rats; rats vs. voles). Even in intact, cycling rats, variations in levels of BDNF mRNA were seen in different hippocampal areas during proestrus [see 14, 19], which may be attributed to different times of sacrifice during that phase [19]. Scharfman et al. [20] found an increase in BDNF immunoreactivity on the day of proestrus and on the morning of estrus, compared to that seen on the day of metestrus or in ovariectomized rats. Although the highest concentration of BDNF was seen in the mossy fiber axons of dentate gyrus granule cells, increased immunoreactivity was also seen in neuropil containing dendrites of CA1 and CA3 neurons. The estrus cycle changes in BDNF corresponded to alterations in neurophysiological responses in CA1 and CA3 neurons to Schaffer collateral stimulation or repetitive hilar stimuli, respectively; slices taken from ovariectomized animals showed no hyperexcitability in the CA3 region. Cavus and Duman [19] found no differences in levels of BDNF mRNA in the $\mathrm{CA} 1$ and $\mathrm{CA} 3$ regions following chronic $\mathrm{E}_{2}$ treatment $\left(\mathrm{E}_{2}\right.$ pellet delivery for 2 weeks) of ovariectomized rats. In our study, we observed an $\mathrm{E}_{2}$-induced increase in BDNF immunolabeling and levels of mRNA for BDNF in those 
regions. This discrepancy may be due to the length of time ovariectomized prior to hormonal treatment, i.e., less than a month in the present study vs. 3 months in the study of Cavus and Duman [19]. These differences are consistent with the notion that $\mathrm{E}_{2}$ replacement is effective in altering BDNF mRNA levels if given soon after ovariectomy, but become refractive if given after prolonged $\mathrm{E}_{2}$ deprivation $[13,92]$. Whether or not the responsiveness of the $b d n f$ gene to $\mathrm{E}_{2}$ is an issue is unknown at present because the observed $\mathrm{E}_{2}$ effects on BDNF mRNA may be direct, possibly via an ERE in the $b d n f$ gene [93, see also 94] or indirect via CREB signaling.

\section{Significance}

The percent of $E_{2}$-induced increases in protein levels of CREB, pCREB, BDNF and mRNA levels of BDNF mRNA in the medial amygdala range from about 24 to $30 \%$ and in the hippocampus, from about 24 to $39 \%$ (except for hippocampal CREB levels themselves). That alterations of this magnitude in the levels of pCREB can alter behavior is evidenced from studies from Pandey et al. [61], who showed that using alcohol-withdrawn (24 h) rats following chronic alcohol administration (15 days) or pharmacological manipulations of CREB phosphorylation, a $32 \%$ decrease in pCREB resulted in a significant reduction in open arm activity (entries and percent time spent on open arms) in the elevated plus maze. In addition, about $40 \%$ reductions in CREB and pCREB protein levels are associated with $40 \%$ reductions in the protein levels of BDNF in the amygdala and hippocampal structures of CREB haplodeficient mice and behaviorally these mice displayed depression and anxiety-like behaviors [60].

Since CREB along with BDNF function has been implicated in cognition, depression and anxiety-like behaviors [62, 95-97, see also 98], it is possible that ability of $\mathrm{E}_{2}$ to increase CREB and BDNF function in selected circuitry of the amygdala and hippocampus may related to its positive effects on the same type of behaviors. Thus, the CREB signaling cascade represents a potential pathway for $\mathrm{E}_{2}$ 's neuroprotective effects. Also, growth effects of $E_{2}$ have been well documented [for reviews, see 1,2] and many of these actions may occur via increased BDNF or other neurotrophic factors. The resultant increased survival of neural circuits and/or strengthening of neural connectivity may counteract some of the deleterious effects of stress on the brain that may ultimately lead to depression [44; see discussion in 33]. Nibuya et al. [99] have shown that the downregulation of BDNF mRNA in response to stress is inhibited by long-term antidepressant treatment. BDNF infused into the midbrain [48] or hippocampus [49] has been shown to have antidepressant properties in the forced swim test, a test for the efficacy of antidepressants in rodents [100]. Overexpression of CREB in the hippocampus also alters behavior in the forced swim test [22]. We have shown an ameliorative effect of $E_{2}$, albeit with a shorter regimen $\left(10 \mu \mathrm{g} E_{2}\right.$ for 7 days), in the forced swim test [58]. The trophic effects of $\mathrm{E}_{2}$, acting either by genomic mechanisms or non-genomic mechanisms, such as have reported in the present study, may raise the threshold for stress-related neuronal damage. These molecular pathways may also be part of the normal repertoire for several steroid-sensitive neuronal circuits [1].

Our data identify a signaling pathway through which $\mathrm{E}_{2}$ increases the expression of BDNF that may underlie some of the effects of $E_{2}$ on affective and cognitive function. Our immunogold experiments localizing the $\mathrm{E}_{2}$ effect on components of this pathway to the medial and basomedial amygdala and CA1 and/or CA3 hippocampus. Moreover, our results indicate the heterogeneity of the $\mathrm{E}_{2}$ effect in the amygdala and hippocampus. Chronic administration of some antidepressants increased CREmediated gene transcription and phosphorylation of CREB in specific subdivisions of the amygdala [101] and hippocampus [101, 102]. That $\mathrm{E}_{2}$ can regulate various components of the CREB signaling and BDNF in specific limbic areas suggests an ability of this hormone to modulate subtleties of neuronal function that are involved in complex behaviors and individual differences associated with them.

\section{Acknowledgments}

This work was supported in part by grants from the National Institute on Alcohol Abuse and Alcoholism (AA10005 and AA13341) and the Department of Veterans Affairs (Merit Review Grant) to S.C.P. and the National Institutes of Mental Health (MH065990) and the Earl M. Bane Charitable Trust to R.S.C. 


\section{References}

1 Woolley CS, Cohen RS: Sex steroids and neuronal growth in adulthood; in Pfaff DW (ed): Hormones, Brains and Behavior. New York, Academic Press, 2002, vol 4, pp 717-777.

-2 Scharfman HE, MacLuskey NJ: Similarities between actions of estrogen and BDNF in the hippocampus: Coincidence or clue? Trends Neurosci 2005;28:79-85.

-3 Pfaff DW: Hormone-driven mechanisms in the central nervous system facilitate the analysis of mammalian behaviors. J Endocrinol 2005; 184:447-453.

4 Cohen RS, Pfaff DW: Ultrastructure of neurons in the ventromedial nucleus of the hypothalamus in ovariectomized rats with or without estrogen treatment. Cell Tissue Res 1981; 217:451-470.

$\checkmark 5$ Chung SK, Pfaff DW, Cohen RS: Estrogen-induced alterations in synaptic morphology in the midbrain central gray. Exp Brain Res 1988; 69:522-530.

-6 Frankfurt M, Gould E, Woolley CS, McEwen BS: Gonadal steroids modify dendritic spine density in ventromedial hypothalamic neurons: A Golgi study in the adult rat. Neuroendocrinology 1990;51:530-535.

7 Calizo LH, Flanagan-Cato LM: Estrogen selectively regulates spine density within the dendritic arbor of rat ventromedial hypothalamic neurons. J Neurosci 2000;20:1589-1596.

-8 Woolley CS, McEwen BS: Estradiol mediates fluctuation in hippocampal synapse density during the estrous cycle in the adult rat. J Neurosci 1992;12:2549-2554.

-9 Rasia-Filho AA, Fabian C, Rigoti KM, Achaval M: Influence of sex, estrous cycle and motherhood on dendritic spine density in the rat medial amygdala revealed by the Golgi method. Neuroscience 2004;126:839-847.

10 Murphy DD, Cole NB, Greenberger V, Segal $M$ : Estradiol increases dendritic spine density by reducing GABA neurotransmission in hippocampal neurons. J Neurosci 1998;18:25502559.

11 Rudick CN, Woolley CS: Estrogen regulates functional inhibition of hippocampal CA1 pyramidal cells in the adult female rat. J Neurosci 2001;21:6532-6543.

12 Sohrabji F, Miranda RCG, Toran-Allerand $\mathrm{CD}$ : Identification of a putative estrogen response element in the gene encoding brain-derived neurotrophic factor. Proc Natl Acad Sci USA 1995;92:11110-11114.

13 Singh M, Meyer EM, Simpkins JW: The effect of ovariectomy and estradiol replacement on brain-derived neurotrophic factor messenger ribonucleic acid expression in cortical and hippocampal brain regions of female SpragueDawley rats. Endocrinology 1995;136:23202324.

14 Gibbs RB: Levels of trkA and BDNF mRNA, but not NGF mRNA, fluctuate across the estrous cycle and increase in response to acute hormone replacement. Brain Res 1998;787: 259-268.
15 Gibbs RB: Treatment with estrogen and progesterone affects relative levels of brain-derived neurotrophic factor mRNA and protein in different regions of the adult rat brain. Brain Res 1999;844:20-27.

16 Jezierski MK, Sohrabji F: Region- and peptide-specific regulation of the neurotrophins by estrogen. Brain Res Mol Brain Res 2000;85: 77-84.

17 Liu Y, Fowler CD, Young LJ, Yan Q, Insel TR, Wang Z: Expression and estrogen regulation of brain-derived neurotrophic factor gene and protein in the forebrain of female prairie voles. J Comp Neurol 2001;433:499-514.

18 Solum DT, Handa RJ: Estrogen regulates the development of brain-derived neurotrophic factor mRNA and protein in the rat hippocampus. J Neurosci 2002;22:2650-2659.

19 Cavus I, Duman, RS: Influence of estradiol, stress, and 5- $\mathrm{HT}_{2 \mathrm{~A}}$ agonist treatment on brainderived neurotrophic factor expression in female rats. Biol Psychiatry 2003;54:59-69.

20 Scharfman HE, Mercurio TC, Goodman JH, Wilson MA, McLusky NJ: Hippocampal excitability increases during the estrus cycle in the rat: A potential role for brain-derived neurotrophic factor. J Neurosci 2003;23:1164111652.

21 Finkbeiner S, Tavazoie SF, Maloratsky A, Jacobs KM, Harris KM, Greenberg ME: CREB: A major mediator of neuronal neurotrophin responses. Neuron 1997;19:1031-1047.

-22 Tao X, Finkbeiner S, Arnold, DB, Shaywitz AJ, Greenberg $\mathrm{ME}: \mathrm{Ca}^{2+}$ influx regulates BDNF transcription by a CREB family transcription factor-dependent mechanism. Neuron 1998;20:709-726.

23 Finkbeiner S: Calcium regulation of the brainderived neurotrophic factor gene. Cell Mol Life Sci 2000;57:394-401.

24 Kobierski LA, Wong AE, Srivastava S, Borsook D, Hyman SE: Cyclic AMP-dependent activation of the proenkephalin gene requires phosphorylation of CREB at serine-133 and a Src-related kinase. J Neurochem 1999;73:129_ 138.

25 Wilson BE, Mochon E, Boxer LM: Induction of bcl-2 expression by phosphorylated CREB proteins during B-cell activation and rescue from apoptosis. Mol Cell Biol 1996;16:55465556.

26 Panickar KS, Guan G, King MA, Simpkins JW: $17 \beta$-Estradiol attenuates CREB decline in the rat hippocampus following seizure. J Neurobiol 1997;3:961-967.

$27 \mathrm{Gu}$ G, Rojo AA, Zee MC, Yu J, Simerly RB: Hormonal regulation of CREB phosphorylation in the anteroventral periventricular nucleus. J Neurosci 1996;16:3035-3044.

28 Zhou Y, Watters JJ, Dorsa DM: Estrogen rapidly induces the phosphorylation of the cAMP response element-binding protein in rat brain. Endocrinology 1996;137:2163-2166.
29 Beyer C, Karolczak M: Estrogenic stimulation of neurite growth in midbrain dopaminergic neurons depends on cAMP/protein kinase A signalling. J Neurosci Res 2000;59:107-116.

30 Abrahám IM, Han SK, Todman MG, Korach $\mathrm{KS}$, Herbison AE: Estrogen receptor- $\beta$ mediates rapid estrogen actions on gonadotropinreleasing hormone neurons in vivo. J Neurosci 2003;23:5771-5777.

31 Abrahám IM, Todman MG, Korach KS, Herbison AE: Critical in vivo roles for classical estrogen receptors in rapid estrogen actions on intracellular signaling in mouse brain. Endocrinology 2004;145:3055-3061

32 Abrahám M, Herbison AE: Major sex differences in non-genomic estrogen actions on intracellular signaling in mouse brain in vivo. Neuroscience 2005;131:945-951.

33 Carlstrom L, Ke Z, Unnerstall JR, Cohen RS, Pandey SC: Estrogen modulation of the cyclic AMP response element-binding protein pathway: Effects of long-term and acute treatments. Neuroendocrinology 2001;74;227-243.

34 Zhou J, Cohen RS, Pandey SC: Estrogen affects the expression of $\mathrm{Ca}^{2+} /$ calmodulin-dependent protein kinase IV in amygdala. Neuroreport 2001;12:1-4.

35 Zhou J, Pandey SC, Cohen RS: Estrogen decreases the expression of calcineurin in rat amygdala and hippocampus. Neuroreport 2004; 15:2437-2440.

36 Bito H, Deisseroth K, Tsien RW: CREB phosphorylation and dephosphorylation: $\mathrm{A} \mathrm{Ca}^{2+}$ and stimulus duration-dependent switch for hippocampal gene expression. Cell 1996;87: 1203-1214.

-37 Hays J, Ockene J, Brunner RL, Kotchen JM, Manson JE, Patterson R, Aragaki AK, Shumaker SA, Brzyski RG, LaCroix AZ, Granek IA, Valanis BG: Effects of estrogen plus progestin on health-related quality of life. N Engl J Med 2003;348:1839-1854.

$\checkmark 38$ De Novaes Soares C, Almeida OP, Joffe H, Cohen LS: Efficacy of estradiol for the treatment of depressive disorders in perimenopausal women: A double-blind, randomized, placebo-controlled trial. Arch Gen Psychiatry 2001;58:529-534.

39 Schmidt PJ, Nieman L, Danaceau MA, Tobin MB, Roca C, Murphy JH, Rubinow DR: Estrogen replacement in perimenopause-related depression: A preliminary report. Am J Obstet Gynecol 2000;183:414-420.

40 Ragson NL, Altshuler LL, Fairbanks LA, Dunkin JJ, Davtyan C, Elman S, Rapkin A: Estrogen replacement therapy in the treatment of major depressive disorder in perimenopausal women. J Clin Psychiatry 2002;63:45-48.

41 Rubinow DR, Schmidt PJ, Roca CA: Estrogenserotonin interactions: Implications for affective regulation. Biol Psychiatry 1998;44:839850 . 
42 Rubinow DR, Schmidt PJ, Roca CA, Daly RC: Gonadal hormones and behavior in women: concentration versus context; in Pfaff DW (ed): Hormones, Brain and Behavior. New York, Academic Press, 2002, vol 5, pp 37-73.

43 Rachman I, Unnerstall JR, Pfaff DW, Cohen RS: Estrogen alters behavior and forebrain cfos expression in ovariectomized rats subjected to the forced swim test. Proc Natl Acad Sci USA 1998;95:13941-13946.

-44 Duman RS, Heninger GR, Nestler EJ: A molecular and cellular theory of depression. Arch Gen Psychiatry 1997;54:597-606.

-45 Soderling TR: CaM-kinases: Modulators of synaptic plasticity. Curr Opin Neurobiol 2000; 10:375-380.

46 O'Connell C, Gallagher HC, O'Malley A, Bourke M, Regan CM: CREB Phosphorylation coincides with transient synapse formation in rat hippocampal dentate gyrus following learning avoidance. Neural Plast 2000;7:279-289.

-47 Marie H, Morishita W, Yu X, Calakos N, Malenka RC: Generation of silent synapses by acute in vivo expression of CaMK IV and CREB. Neuron 2005;45:741-752.

48 Siuciak JA, Lewis DR, Wiegand SJ, Lindsay, RM: Antidepressant-like effect of brain-derived neurotrophic factor. Pharmacol Biochem Behav 1997;56: 131-137.

-49 Shirayama Y, Chen ACH, Nakagawa S, Russell DS, Duman RS: Brain-derived neurotrophic factor produces antidepressant effects in behavior models of depression. J Neurosci 2002;22:3251-3261.

- 50 Dias BG, Banerjee SB, Duman RS, Vaidya VA: Differential regulation of brain derived neurotrophic factor transcripts by antidepressant treatments in the adult rat brain. Neuropharmacology 2003;45:553-563.

-51 Monteggia LM, Barrot M, Powell CM, Berton O, Galanis V, Gemelli T, Meuth S, Nagy A, Greene RW, Nestler EJ: Essential role of brainderived neurotrophic factor in adult hippocampal function. Proc Natl Acad Sci USA 2004; 101:10827-10832.

- 52 Hoshaw BA, Malberg JE, Lucki I: Central administration of IGF-I and BDNF leads to longlasting antidepressant-like effects. Brain Res 2005;37:204-208.

-53 Hashimoto K, Shimizu E, Iyo M: Critical role of brain-derived neurotrophic factor in mood disorders. Brain Res Brain Res Rev 2004;45: 104-114.

54 Jiang X, Xu K, Hoberman J, Tian F, Marko AJ, Waheed JF, Harris CR, Marini AM, Enoch MA, Lipsky RH: BDNF variation and mood disorders: A novel functional promoter polymorphism and Val66Met are associated with anxiety but have opposing effects. Neuropsychopharmacology 2005;16:1-9.

-55 Egan MF, Kojima M, Callicott JH, Goldberg TE, Kolachana BS, Bertolino A, Zaitsev E, Gold B, Goldman D, Dean M, Lu B, Weinberger DR: The BDNF val66met polymorphism affects activity-dependent secretion of BDNF and human memory and hippocampal function. Cell 2003;112:257-269.
56 Kow LM, Pfaff DW: Induction of lordosis in female rats: Two models of estrogen action and the effect of adrenalectomy. Horm Behav 1975;6:259-276.

57 Pfaff, DW: Estrogen and Brain Function. Neural Analysis of a Hormone-Controlled Mammalian Reproductive Behavior. New York, Springer, 1980.

-58 Rachman IM, Unnerstall JR, Pfaff DW, Cohen RS: Regulation of neuronal nitric oxide synthase mRNA in lordosis-relevant neurons of the ventromedial hypothalamus following short-term estrogen treatment. Brain Res Mol Brain Res 1998;59:105-108.

59 Pandey SC, Roy A, Mittal N: Effects of chronic ethanol intake and its withdrawal on the expression and phosphorylation of the CREB gene transcription factor in rat cortex. J Pharmacol Exp Ther 2001;296:857-868.

60 Pandey SC, Roy A, Zhang H, Xu T: Partial deletion of the cAMP response element-binding protein gene promotes alcohol-drinking behaviors. J Neurosci 2004;24:5022-5030.

61 Pandey SC, Roy A, Zhang H: The decreased phosphorylation of cyclic adenosine monophosphate response element-binding protein in the central amygdala acts as a molecular substrate for anxiety related to ethanol withdrawal in rats. Alcohol Clin Exp Res 2003;27:396409.

62 Pesold C, Caruncho HJ, Impagnatiello F, Berg MJ, Fritschy JM, Guidotti A, Costa E: Tolerance to diazepam and changes in $\mathrm{GABA}_{\mathrm{A}}$ receptor subunit expression in rat neocortical areas. Neuroscience 1997;79:477-487.

63 Izzo E, Auta J, Impagnatiello F, Pesold C, Guidotti A, Costa E: Glutamic acid decarboxylase and glutamate receptor changes during tolerance and dependence to benzodiazepines. Proc Natl Acad Sci USA 2001;98:3483-3488.

64 Paxinos SG, Watson, C: The Rat Brain in Sterotaxic Coordinates. New York, Academic Press, 1998.

65 Pandey SC, Mittal N, Lumeng L, Li TK: Involvement of the cyclic AMP-responsive element-binding protein gene transcription factor in genetic preference for alcohol drinking behavior. Alcohol Clin Exp Res 1999;23:14251434.

66 Zhang H, Pandey SC: Effects of PKA modulation on the expression of neuropeptide $\mathrm{Y}$ in rat amygdaloid structures during ethanol withdrawal. Peptides 2003;24:1397-1402.

67 Bates PJ, Sanderson G, Holgate ST, Johnston SL: A comparison of RT-PCR, in-situ hybridisation and in-situ RT-PCR for the detection of rhinovirus infection in paraffin sections. J Virol Methods 1997;67:153-160.

-68 Enslen H, Sun P, Brickey D, Soderling SH, Klamo E, Soderling TR: Characterization of $\mathrm{Ca}^{2+} /$ calmodulin-dependent protein kinase IV. Role in transcriptional regulation. J Biol Chem 1994;269:15520-15527.

69 Kasahara J, Fukunaga K, Miyamoto E: Activation of calcium/calmodulin-dependent protein kinase IV in long-term potentiation in the rat hippocampal CA1 region. J Biol Chem 2001; 276:24044-24050.
70 Ho N, Liauw JA, Blaeser F, Wei F, Hanissian S, Muglia LM, Wozniak DF, Nardi A, Arvin KL, Holtzman DM, Linden DJ, Zhou M, Muglia LJ, Chatila TA: Impaired synaptic plasticity and cAMP response element-binding protein activation in $\mathrm{Ca}^{2+} /$ calmodulin-dependent protein kinase type IV/Gr-deficient mice. J Neurosci 2000;20:6459-6472.

71 Ribar TJ, Rodriguiz RM, Khiroug L, Wetsel WC, Augustine GJ, Means AR: Cerebellar defects in $\mathrm{Ca}^{2+} /$ calmodulin kinase IV-deficient mice. J Neurosci 2000;20:RC107.

72 Wu JY, Gonzalez-Robayna IJ, Richards JS, Means AR: Female fertility is reduced in mice lacking $\mathrm{Ca}^{2+} /$ calmodulin-dependent protein kinase IV. Endocrinology 2000;41: 4777-4783.

73 Zhao L, Chen S, Ming Wang J, Brinton RD: 17ß-Estradiol induces $\mathrm{Ca}^{2+}$ influx, dendritic and nuclear $\mathrm{Ca}^{2+}$ rise and subsequent cyclic AMP response element-binding protein activation in hippocampal neurons: A potential initiation mechanism for estrogen neurotropism. Neuroscience 2005;132:2299-3111.

74 Tiraboschi E, Tardito D, Kasahara J, Moraschi S, Pruneri P, Gennarelli M, Racagni G, Popoli M: Selective phosphorylation of nuclear CREB by fluoxetine is linked to activation of CaM kinase IV and MAP kinase cascades. Neuropsychopharmacology 2004;29:18311840.

75 Funabashi T, Brooks PJ, Kleopoulos SP, Grandison L, Mobbs CV, Pfaff DW: Changes in preproenkephalin messenger RNA level in the rat ventromedial hypothalamus during the estrous cycle. Mol Brain Res 1995;28:129-134.

76 Sharrow KM, Kumar A, Foster TC: Calcineurin as a potential contributor in estradiol regulation of hippocampal synaptic function. Neuroscience 2002;113:89-97.

77 Killcross S, Robbins TW, Everitt BJ: Different types of fear-conditioned behaviour mediated by separate nuclei within amygdala. Nature 1997;388:377-380.

78 Krężel W, Dupont S, Krust A, Chambon P, Chapman PF: Increased anxiety and synaptic plasticity in estrogen receptor- $\beta$-deficient mice. Proc Natl Acad Sci USA 2001;98:122782282

79 Womble MD, Andrew JA, Crook JJ: 17ß-Estradiol reduces excitatory postsynaptic potential amplitude in rat basolateral amygdale neurons: Neurosci Lett 2002;331:83-86.

80 Morgan MA, Schulkin J, Pfaff DW Estrogens and non-reproductive behaviors related to activity and fear. Neurosci Behav Rev 2004;28: 55-63.

81 Davis M, Rannie D, Cassel M: Neurotransmission in the rat amygdala related to fear and anxiety. Trends Neurosci 1994;17:208-214.

82 Shughrue PJ, Lane MV, Merchenthaler I: comparative distribution of estrogen receptor- $\alpha$ and $-\beta$ RNA in the rat central nervous system. J Comp Neurol 1997;388:507-525. 
-83 Österlund MK, Kuiper GJM, Gustafsson J, Hurd YL: Differential distribution and regulation of estrogen receptor- $\alpha$ and $-\beta$ mRNA within the female rat brain. Mol Brain Res 1998; 54:175-180.

84 Österlund MK, Hurd YL: Estrogen receptors in the human forebrain and the relation to neuropsychiatric disorders. Prog Neurobiol 2001; 64:251-267.

85 Shima N, Yamaguchi Y, Yuri K: Distribution of estrogen receptor- $\beta$ mRNA-containing cells in ovariectomized and estrogen-treated female rat brain. Anat Sci Int 2003;78:85-97.

-86 Shughrue PJ, Scrimo PJ, Merchenthaler I: Evidence for the colocalization of estrogen receptor- $\beta$ mRNA and estrogen receptor- $\alpha$ immunoreactivity in neurons of the rat forebrain. Endocrinology 1998 139;5267-5270.

-87 Pliakas AM, Carlson RR, Neve RL, Konradi C, Nestler EJ, Carlezon WA Jr: Altered responsiveness to cocaine and increased immobility in the forced swim test associated with elevated cAMP response element-binding protein expression in nucleus accumbens. J Neurosci 2001;21:7397-403.

88 Newton SS, Thome J, Wallace TL, Shirayama Y, Schlesinger L, Sakai N, Chen J, Neve R, Nestler EJ, Duman RS: Inhibition of cAMP response element-binding protein or dynorphin in the nucleus accumbens produces an antidepressant-like effect. J Neurosci 2002;22: 10883-10890.

-89 Ramos BP, Birnbaum SG, Lindenmayer I, Newton SS, Duman RS, Arnsten AF: Dysregulation of protein kinase a signaling in the aged prefrontal cortex: New strategy for treating age-related cognitive decline. Neuron 2003; 40 : 835-845.
90 Wallace TL, Stellitano KE, Neve RL, Duman RS: Effects of cyclic adenosine monophosphate response element-binding protein overexpression in the basolateral amygdala on behavioral models of depression and anxiety. Biol Psychiatry 2004;56:151-160.

91 Frye CA, Walf AA: Estrogen and/or progesterone administered systemically or to the amygdala can have anxiety-, fear-, and pain-reducing effects in ovariectomized rats. Behav Neurosci 2004;118:306-313.

92 Berchtold NC, Kesslak JP, Pike CJ, Adlard PA, Cotman CW: Estrogen and exercise interact to regulate brain-derived neurotrophic factor mRNA and protein expression in the hippocampus. Eur J Neurosci 2001;14:1992-2002.

93 Toran-Allerand CD: The estrogen/neurotrophin connection during neural development: Is co-localization of estrogen receptors with the neurotrophins and their receptors biologically relevant? Dev Neurosci 1996;18:36-48.

94 Klein-Hitpass L, Ryffel GU, Heitlinger E, Cato AC: A 13-bp palindrome is a functional estrogen responsive element and interacts specifically with estrogen receptor. Nucleic Acids Res 1988;6:647-663.

95 Silva AJ, Kogan JH, Frankland PW, Kida S: CREB and memory. Annu Rev Neurosci 1998; 21:127-148.

-96 Pandey SC: Anxiety and alcohol abuse disorders: A common role for CREB and its target, the neuropeptide $\mathrm{Y}$ gene. Trends Pharmacol Sci 2003;24:456-460.
-97 Conti AC, Cryan JF, Dalvi A, Lucki I, Blendy JA: cAMP response element-binding protein is essential for the upregulation of brain-derived neurotrophic factor transcription, but not the behavioral or endocrine responses to antidepressant drugs. J Neurosci 2002;22: 3262-3268.

98 Valverde O, Mantamadiotis T, Torrecilla M, Ugedo L, Pineda J, Bleckmann S, Gass P, Kretz O, Mitchell JM, Schütz G, Maldonado R: Modulation of anxiety-like behavior and morphine dependence in CREB-deficient mice. Neuropsychopharmacology 2004;29: 1122-1133.

99 Nibuya M, Morinobu S, Duman RS: Regulation of BDNF and trkB in rat brain by chronic electroconvulsive seizure and antidepressant drug treatments. J Neurosci 1995; 15: 7539-7547.

100 Porsolt RD, Anton G, Blavet N, Jalfre M: Behavioural despair in rats: A new model sensitive to antidepressant treatments. Eur J Pharmacol 1978;47: 379-391.

101 Thome J, Sakai N, Shin KH, Steffen C, Zhang YJ, Impey S, Storm D, Duman R: cAMP response element-mediated gene transcription is upregulated by chronic antidepressant treatment. J Neurosci 2000;20: 4030-4036.

102 Itoh T, Tokumura M, Abe K: Effects of rolipram, a phosphodiesterase-4 inhibitor, in combination with imipramine on depressive behavior, CRE-binding activity and BDNF level in learned helplessness rats. Eur J Pharmacol 2004;498:135-142. 